\title{
BUILDING STANDARDS FOR STUDENT PHYSICAL ASSESSMENT FIRST YEAR LAOS NATIONAL UNIVERSITY
}

\author{
Dam Trung Kien ${ }^{1 i}$, \\ Bounly Patsaphanh ${ }^{2}$ \\ 1Dr., Bac Ninh Sports University of Vietnam, \\ Vietnam \\ ${ }^{2}$ Laos National University, \\ Laos
}

\begin{abstract}
:
Research to build physical assessment standards for first-year students of Lao National University helps us get the basic information and basis to evaluate teaching process, choose solutions. suitable in the training process, improve students' physical condition to meet learning requirements in new training trends.
\end{abstract}

Keywords: standard, physical, student, Laos National University

\section{Introduction}

Grasping the importance of financial education for students, many universities across the country, including Laos National University have fully implemented the regulations of the Ministry of Education and Sports regarding the program content. GDTC in Universities. In fact, in teaching at the school, we found that, in the teaching of financial education for students during the lessons, many students still showed weak physical characteristics, poor physical condition, leading to failure to fulfill the set targets of subject, this more or less affects students' learning results and the quality of the school's training.

To accurately determine the physical status of students to not only meet the requirements of improving fitness and developing physical fitness, but also meeting the needs and preferences of students, reducing stress after studying. reasoning in class. Thereby helping students to complete and develop the necessary qualities and competencies, to meet the demanding requirements of society, and to improve the personality of the staff in the future. Therefore, the physical assessment of first-year students of the National University of Laos has then taken appropriate measures to help students define their learning goals, motivations and stimulate their learning needs.

i Correspondence: email nguyenducthanh71@gmail.com 
members, improving the efficiency of financial education to meet output requirements for society.

\section{Research Methods}

In the research process, we have used the following methods: Document reference method, pedagogical observation method, interview method, pedagogical test method and statistical mathematical method. Conducted surveys and assessments on male and female students of Laos National University. Interviewing experts, lecturers from universities in the province of Laos to determine the content of students' physical assessment.

\section{Research Results}

\subsection{Determine the content of physical assessment for students of Laos National University}

Through the analysis and synthesis of documents, we have a system of 9 tests used by many experts and lecturers to evaluate students' physical fitness. The final result of the interview is optimal if there is a high coincidence between two interviews. We conducted two interviews one month apart with the same affirmative or disapproving response. From the results obtained through the interview process, we have selected 9 physical assessment tests with a high number of votes (over $80 \%$ ) of experts and lecturers.

From the obtained results, we determine the informativeness showing that: All 9/9 tests selected in the research object show a fully informative correlation with $(|\mathrm{r}|>\mid 0.6$ I with $\mathrm{p}<0.05)$ and determine the reliability of the tests. Through 2 tests at a very high level (with $r>0.80$ to 0.99 at the threshold probability $\mathrm{p}<0.05$. This shows that the selected tests show a strong correlation with full reportability, reliable enough and suitable for research subjects as well as practical conditions in the physical assessment for students of Laos National University.

The tests are: Lie on your stomach for 20 seconds (times), Turn on the spot $(\mathrm{cm})$, Lie on your back for 30 seconds (times), Run 30m (s), Run 4x10m (s), Run arbitrarily 12 minutes $(\mathrm{m})$, Corresponding height $(\mathrm{cm})$, HW index, Live capacity (liters).

\subsection{Develop standards to assess the fitness of first-year students at Lao National University}

To evaluate the physical fitness of the students of the National University of Laos. We have tested the pedagogy on 9 selected tests, on that basis, building a physical assessment scale for research subjects in 2 forms of classification and points, namely: Based on the results identified from 9 physical assessment tests, by value, we built a classification table according to 5 levels: Good, Fair, Medium, Weak, Poor. Content with test results of distance, altitude, magnitude, number of times is as large as possible, and vice versa, the results measured by time, the smaller the better.

The scale with test results as large as possible is built as follows: 
$<-1.5$ Poor

$-1.5 \sim-0.5$ Weak

$-0.5 \sim+0.5$ Average

$+0.5 \sim+1.5$ Fair

$>+1.5 \mathrm{Good}$

The scale with test results as small as possible is constructed as follows:

+1.5 Poor

$+0.5 \sim+1.5$ Weak

$-0.5 \sim+0.5$ Average

- $1.5 \sim-0.5$ Fair

-1.5 Good

After the 9-test pedagogical test, we built the scoreboard according to the 5-level classification presented in tables $1,2$.

Table 1: Criteria for first-year male student's physical fitness classification Laos National University

\begin{tabular}{|c|l|c|c|c|c|c|}
\hline No. & Content & Good & Fair & Average & Weak & Poor \\
\hline 1. & $\begin{array}{l}\text { Lie on your stomach for 20 seconds } \\
\text { (times) }\end{array}$ & $\geq 19.8$ & $19.7-16.7$ & $16.6-13.5$ & $13.4-10.4$ & $\leq 10.3$ \\
\hline 2. & Turn on the spot (cm) & $\geq 250.1$ & $250.0-229.5$ & $229.4-208.7$ & $208.6-188.1$ & $\leq 188.0$ \\
\hline 3. & Lie on your back for 30 seconds (times) & $\geq 23.2$ & $23.1-19.3$ & $19.2-15.2$ & $11.2-15.1$ & $\leq 11.1$ \\
\hline 4. & Run 30m (s) & $\leq 4.30$ & $4.31-4.82$ & $4.81-5.31$ & $5.32-5.81$ & $\geq 5.82$ \\
\hline 5. & Run 4x10m (s) & $\leq 9.6$ & $9.7-10.2$ & $10.3-10.8$ & $10.9-11.4$ & $\geq 11.5$ \\
\hline 6. & Run arbitrarily 12 minutes (m) & $\geq 2015$ & $2014-1935$ & $1934-1853$ & $1852-1773$ & $\leq 1772$ \\
\hline 7. & Corresponding height (cm) & $\geq 171.9$ & $171.8-166.4$ & $166.3-160.9$ & $160.8-155.4$ & $\leq 155.3$ \\
\hline 8. & HW index & $\leq 6.8$ & $6.9-9.6$ & $9.5-12.1$ & $12.2-14.6$ & $\geq 14.7$ \\
\hline 9. & Live capacity (liters) & $\geq 5.1$ & $5.0-4.4$ & $4.3-3.6$ & $3.62-2.92$ & $\leq 2.91$ \\
\hline
\end{tabular}

Table 2: Criteria for first-year female student's physical fitness classification Laos National University

\begin{tabular}{|c|l|c|c|c|c|c|}
\hline No. & Content & Good & Fair & Average & Weak & Poor \\
\hline 1. & $\begin{array}{l}\text { Lie on your stomach for } 20 \\
\text { seconds (times) }\end{array}$ & $\geq 14.5$ & $14.4-11.9$ & $11.8-9.1$ & $9.0-6.5$ & $\leq 6.4$ \\
\hline 2. & Turn on the spot (cm) & $\geq 162.4$ & $162.3-158$ & $157.9-153.4$ & $153.3-149$ & $\leq 148$ \\
\hline 3. & $\begin{array}{l}\text { Lie on your back for } 30 \\
\text { seconds (times) }\end{array}$ & $\geq 15.8$ & $15.7-12.6$ & $12.5-9.4$ & $9.3-6.2$ & $\leq 6.1$ \\
\hline 4. & Run 30m (s) & $\leq 4.9$ & $5.0-5.72$ & $5.73-6.46$ & $6.47-7.2$ & $\geq 7.1$ \\
\hline 5. & Run 4x10m (s) & $\leq 10.9$ & $11.0-11.2$ & $11.3-11.7$ & $11.8-12.1$ & $\geq 12.2$ \\
\hline 6. & $\begin{array}{l}\text { Run arbitrarily 12 minutes } \\
\text { (m) }\end{array}$ & $\geq 1524$ & $1523-1463$ & $1462-1401$ & $1400-1340$ & $\leq 1339$ \\
\hline 7. & Corresponding height (cm) & $\geq 161.5$ & $161.4-158$ & $157-152.6$ & $152.5-148.2$ & $\leq 148.1$ \\
\hline 8. & HW index & $\leq 5.4$ & $5.5-7.3$ & $7.2-8.9$ & $9.0-10.6$ & $\geq 10.7$ \\
\hline 9. & Live capacity (liters) & $\geq 3.94$ & $3.93-3.40$ & $3.39-2.85$ & $2.84-2.31$ & $\leq 2.30$ \\
\hline
\end{tabular}


Based on the C-scale scoreboard (scores from 1 to 10), we built the scoreboard, the results presented in tables 3 and 4 .

Table 3: Standards of physical fitness based on transcripts for male students first-year Lao National University

\begin{tabular}{|c|l|c|c|c|c|c|c|c|c|c|c|}
\hline No. & Test & \multicolumn{10}{|c|}{ Mark } \\
\cline { 2 - 11 } & & $\mathbf{1}$ & $\mathbf{2}$ & $\mathbf{3}$ & $\mathbf{4}$ & $\mathbf{5}$ & $\mathbf{6}$ & $\mathbf{7}$ & $\mathbf{8}$ & $\mathbf{9}$ & $\mathbf{1 0}$ \\
\hline 1. & $\begin{array}{l}\text { Lie on your } \\
\text { stomach for 20 } \\
\text { seconds (times) }\end{array}$ & $<10.4$ & 10.4 & 11.9 & 13.5 & 15.0 & 16.6 & 18.1 & 19.7 & 21.2 & $>21.2$ \\
\hline 2. & $\begin{array}{l}\text { Turn on the spot } \\
\text { (cm) }\end{array}$ & $<188.1$ & 188.1 & 198.4 & 208.7 & 219.0 & 229.4 & 239.7 & 250.0 & 260.3 & $>160.3$ \\
\hline 3. & $\begin{array}{l}\text { Lie on your back } \\
\text { for 30 seconds } \\
\text { (times) }\end{array}$ & $<11.2$ & 11.2 & 13.2 & 15.2 & 17.2 & 19.2 & 21.1 & 23.1 & 25.1 & $>25.1$ \\
\hline 4. & Run 30m (s) & $>5.81$ & 5.81 & 5.56 & 5.31 & 5.06 & 4.81 & 4.56 & 4.31 & 4.06 & $<4.06$ \\
\hline 5. & Run 4x10m (s) & $>11.4$ & 11.4 & 11.1 & 10.8 & 10.6 & 10.3 & 10.0 & 9.7 & 9.5 & $<9.5$ \\
\hline 6. & $\begin{array}{l}\text { Run arbitrarily } 12 \\
\text { minutes (m) }\end{array}$ & $<1773$ & 1773 & 1813 & 1853 & 1893 & 1934 & 1974 & 2014 & 2055 & $>2055$ \\
\hline 7. & $\begin{array}{l}\text { Corresponding } \\
\text { height (cm) }\end{array}$ & $<155.4$ & 155.4 & 158.1 & 160.9 & 163.6 & 166.3 & 169.1 & 171.8 & 174.5 & $>$ \\
\hline 8. & HW index & $<14.6$ & 14.6 & 13.3 & 12.1 & 10.8 & 9.5 & 8.2 & 6.9 & 5.6 & $<5.6$ \\
\hline 9. & $\begin{array}{l}\text { Live capacity } \\
\text { (liters) }\end{array}$ & $<2.9$ & 2.9 & 3.2 & 3.6 & 3.9 & 4.3 & 4.6 & 5.0 & 5.4 & $>5.4$ \\
\hline
\end{tabular}

Table 4: Standards of physical fitness based on transcripts for female students first-year Lao National University

\begin{tabular}{|c|l|c|c|c|c|c|c|c|c|c|c|}
\hline No. & Test & \multicolumn{9}{|c|}{ Mark } \\
\cline { 2 - 11 } & & $\mathbf{1}$ & $\mathbf{2}$ & $\mathbf{3}$ & $\mathbf{4}$ & $\mathbf{5}$ & $\mathbf{6}$ & $\mathbf{7}$ & $\mathbf{8}$ & $\mathbf{9}$ & $\mathbf{1 0}$ \\
\hline 1. & $\begin{array}{l}\text { Lie on your } \\
\text { stomach for 20 } \\
\text { seconds (times) }\end{array}$ & $<6.5$ & 6.5 & 7.8 & 9.1 & 10.5 & 11.8 & 13.1 & 14.4 & 15.8 & $>15.8$ \\
\hline 2. & $\begin{array}{l}\text { Turn on the spot } \\
\text { (cm) }\end{array}$ & $<149$ & 149.0 & 151.2 & 153.4 & 155.7 & 157.9 & 160.1 & 162.3 & 164.6 & $\begin{array}{c}> \\
164.6\end{array}$ \\
\hline 3. & $\begin{array}{l}\text { Lie on your back } \\
\text { for 30 seconds } \\
\text { (times) }\end{array}$ & $<6.2$ & 6.2 & 7.8 & 9.4 & 11.0 & 12.5 & 14.1 & 15.7 & 17.3 & $>17.3$ \\
\hline 4. & Run 30m (s) & $>7.2$ & 7.2 & 6.82 & 6.46 & 6.09 & 5.73 & 5.36 & 5.00 & 4.63 & $<4.63$ \\
\hline 5. & Run 4x10m (s) & $>12.1$ & 12.1 & 11.9 & 11.7 & 11.5 & 11.3 & 11.1 & 11.0 & 10.8 & $<10.8$ \\
\hline 6. & $\begin{array}{l}\text { Run arbitrarily } 12 \\
\text { minutes (m) }\end{array}$ & $<1341$ & 1340 & 1370 & 1401 & 1431 & 1462 & 1492 & 1523 & 1553 & $>$ \\
\hline 7. & $\begin{array}{l}\text { Corresponding } \\
\text { height (cm) }\end{array}$ & $<148.2$ & 148.2 & 150.4 & 152.6 & 154.8 & 157.0 & 159.2 & 161.4 & 163.6 & $>$ \\
\hline 8. & HW index & $<10.6$ & 10.6 & 9.8 & 8.9 & 8.1 & 7.2 & 6.4 & 5.5 & 4.7 & $<4.7$ \\
\hline 9. & $\begin{array}{l}\text { Live capacity } \\
\text { (liters) }\end{array}$ & $<2.31$ & 2.31 & 2.58 & 2.85 & 3.12 & 3.39 & 3.66 & 3.93 & 4.20 & $>4.20$ \\
\hline
\end{tabular}


On the basis of building a standard scale, we assess the student's fitness by pedagogical test 9 tests on first year male and female students of Laos National University giving results in Table 6.

Table 6: Physical situation of the first year students Lao National University

\begin{tabular}{|c|c|c|c|c|c|}
\hline \multirow{2}{*}{ Object } & \multirow{2}{*}{ Test } & \multicolumn{2}{|c|}{ Result } & \multirow{2}{*}{$\begin{array}{c}\text { Number of } \\
\text { people reached }\end{array}$} & \multirow{2}{*}{$\%$} \\
\hline & & $\bar{x}$ & $\mathrm{~S}$ & & \\
\hline \multirow{9}{*}{$\begin{array}{l}\text { Male } \\
(n=223)\end{array}$} & $\begin{array}{l}\text { Lie on your stomach for } 20 \text { seconds } \\
\text { (times) }\end{array}$ & 15.07 & 3.11 & 153 & 68.61 \\
\hline & Turn on the spot $(\mathrm{cm})$ & 219.07 & 20.65 & 91 & 40.81 \\
\hline & $\begin{array}{l}\text { Lie on your back for } 30 \text { seconds } \\
\text { (times) }\end{array}$ & 17.23 & 3.96 & 104 & 46.64 \\
\hline & Run 30m (s) & 5.06 & 0.5 & 142 & 63.68 \\
\hline & Run $4 \times 10 \mathrm{~m}(\mathrm{~s})$ & 10.6 & 0.54 & 138 & 61.88 \\
\hline & Run arbitrarily 12 minutes (m) & 1893.53 & 80.53 & 182 & 81.61 \\
\hline & Corresponding height $(\mathrm{cm})$ & 163.65 & 5.47 & 96 & 43.05 \\
\hline & HW index & 10.81 & 2.58 & 137 & 61.43 \\
\hline & Live capacity (liters) & 3.98 & 0.71 & 132 & 59.19 \\
\hline \multirow{9}{*}{$\begin{array}{l}\text { Female } \\
(n=223)\end{array}$} & $\begin{array}{l}\text { Lie on your stomach for } 20 \text { seconds } \\
\text { (times) }\end{array}$ & 10.51 & 2.65 & 119 & 53.36 \\
\hline & Turn on the spot $(\mathrm{cm})$ & 155.70 & 4.45 & 128 & 57.40 \\
\hline & $\begin{array}{l}\text { Lie on your back for } 30 \text { seconds } \\
\text { (times) }\end{array}$ & 11.00 & 3.15 & 173 & 77.58 \\
\hline & Run 30m (s) & 6.09 & 0.73 & 172 & 77.13 \\
\hline & Run $4 \times 10 \mathrm{~m}(\mathrm{~s})$ & 11.55 & 0.37 & 171 & 76.68 \\
\hline & Run arbitrarily 12 minutes (m) & 1431.55 & 60.9 & 134 & 60.09 \\
\hline & Corresponding height $(\mathrm{cm})$ & 154.80 & 4.4 & 114 & 51.12 \\
\hline & HW index & 8.13 & 1.7 & 108 & 48.43 \\
\hline & Live capacity (liters) & 3.12 & 0.54 & 114 & 51.12 \\
\hline
\end{tabular}

Thus, we see, when building the standards according to the classification and the 10-point scale. The test subjects all have results corresponding to the level of physical and concentration is average (from $40,81-81.61 \%$ for men and $48.43-77.58 \%$ for women), so there are still many below average students. Therefore, there should be measures to guide the physical improvement of the students of the National University of Laos.

\section{Conclusion}

The study has taken steps from which 9 physical assessment tests were selected for first year students of Laos National University. Through the pedagogical test, a 5-level classification table and a C-scale transcript have been built to assess students' physical fitness. The situation assessment step shows that there are still many students who have not reached the average level. It is necessary to have solutions to educate and improve the fitness for students of the National University of Laos to meet new condition. 


\section{Conflict of Interest Statement}

The authors have no conflicts of interest to declare. All co-authors have seen and agree with the contents of the manuscript and there is no financial interest to report. We certify that the submission is original work and is not under review at any other publication.

\section{About the Author}

Dr. Dam Trung Kien:

- Lecturer in athletics, weightlifting (2000-2011)

- Deputy Head of Department of Sports Management (2011-2014)

- Head of Education Quality Assurance and Testing Department (2015 to present)

\section{References}

1. Ministry of Education and Training, Decision No. 53/2008/QD-BGDDT, dated September 18, 2008 on "Assessment of general fitness for students" in Vietnam

2. Nguyen Dang Chieu (2009). "The status of the financial education work of some universities in Ho Chi Minh City and its solutions", Ministry-Vietnam science topic

3. Prime Minister, Decision 641/QD-TTg, dated April 28, 2011, on approval of the Master Project for the development of physical strength and stature of Vietnamese people for the period $2011-2030$

4. Ministry of Education and Sports (2011). Laos National Program Framework

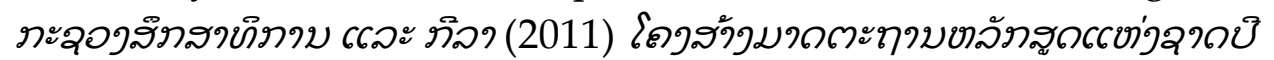

5. Decision No. 3799 / BGDTT.SP, dated 09/09/2013 of the Ministry of Education and Sports, content of physical education in Universities-Laos

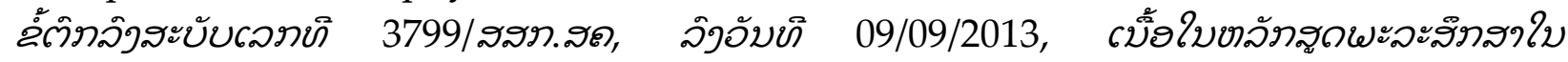
จะทาบับงาบรึังจา.

6. National human resource development strategy until 2030, April 2016 - Laos

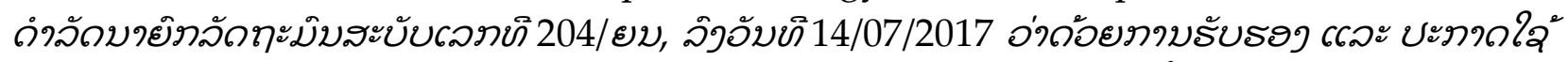

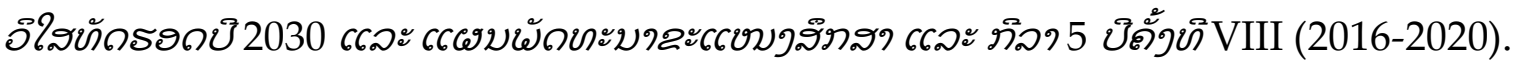


Creative Commons licensing terms

Authors will retain the copyright of their published articles agreeing that a Creative Commons Attribution 4.0 International License (CC BY 4.0) terms will be applied to their work. Under the terms of this license, no permission is required from the author(s) or publisher for members of the community to copy, distribute, transmit or adapt the article content, providing a proper, prominent and unambiguous attribution to the authors in a manner that makes clear that the materials are being reused under permission of a Creative Commons License. Views, opinions and conclusions expressed in this research article are views, opinions and conclusions of the author(s). Open Access Publishing Group and European Journal of Physical Education and Sport Science shall not be responsible or answerable for any loss, damage or liability caused in relation to/arising out of conflict of interests, copyright violations and inappropriate or inaccurate use of any kind content related or integrated on the research work. All the published works are meeting the Open Access Publishing requirements and can be freely accessed, shared, modified, distributed and used in educational, commercial and non-commercial purposes under a Creative Commons attribution 4.0 International License (CC BY 4.0). 